\title{
INFLUENCE OF OPTIMISM UPON THE ACCUMULATION OF STRESS, MENTAL STATE AND PERCEIVED RISKS FOR THE FUTURE OF STUDENTS, IN THE CONDITIONS OF COVID-19 PANDEMIC
}

\author{
Valeri Stoyanov \\ Nikola Vaptsarov Naval Academy (Bulgaria)
}

\begin{abstract}
An empirical psychological study was conducted with students from Nikola Vaptsarov Naval Academy, using both quantitative and qualitative approaches. The aim of the research was to test the role of optimism on the accumulation of stress in the conditions of pandemic of COVID-19, their mental states, experiences in connection with social isolation and perceived risks for the future and career. It has been found that optimism, as a generalized personal expectation, has a strong buffering effect on the impact of accumulated pandemic stress on students' emotional states. Negative expectations do not have a significant effect on the emotional state. Optimism and negative expectations have no effect on fears for the future and perceived risks for young people as a result of the COVID-19 pandemic. Obviously, other personal and social factors determine the negative expectations for the acquired competencies during distance learning online, as well as for more difficult careers and career problems for this reason. More pronounced negative expectations make it more difficult for students to tolerate social isolation, while optimism has no statistically significant impact on social isolation experiences during a pandemic. Students with more optimism perceive their mental state as stable, good, while those with reduced optimism and more pronounced negative expectations as shaky, depressed. The results of the study suggest the need for additional activity of higher education institutions in such conditions to support and advise students.

Keywords: optimism; COVID-19 pandemic; social isolation; accumulated stress; mental stat
\end{abstract}

\section{Introduction}

The COVID-19 pandemic has changed people's lives worldwide. Whole generations have encountered social phenomena for the first time - social 
isolation, enforcement of coercive administrative and hygienic measures, restrictions on mobility, etc. Higher education institutions had to quickly restructure their activities and the alternative was found in distance learning. All this has led to a number of psychological and socio-psychological problems that have different dimensions and have provoked the activity of researchers (Domuschieva et al. 2020). For students, distance learning has raised a number of doubts and fears about the prospects and quality of acquired knowledge and competencies (Naydenova et al. 2020).

In the context of the above, the problem of what happens to students in terms of their experiences, as well as the influence of personal qualities and situational factors on these experiences, is significant.

Insofar as situations of uncertainty and apprised as poorly controllable or uncontrollable cause mental stress, psychology seeks the buffering effect of a number of personal characteristics on this influence (Lazarus 1999). Essential in the mental regulation of the activity are the so-called generalized expectations optimism, localization of control, beliefs in the justice of the world, in personal value (Velichkov 2001). Insofar as the pandemic situation is associated with social isolation and a number of restrictions in life, which brings high levels of stress (Iancheva 2020), the influence of the generalized expectation "Optimism" on people's experiences is of interest. Optimism is associated with the expectation of a positive result and the predominance of positive events in people's lives. In this regard, most of the research related to it focuses on the search for buffering effects against the development of mental stress and especially the effects of stress (Velichkov 2001, 86-96).

\section{Research methodology}

In the context of the above, the aim of the study is to examine the relationships between optimism, stress accumulation and mental state of students in the COVID 19 pandemic, as well as experiences of social isolation and perceived risks to future and career.

The expectations are to reveal the buffering role of the expressed optimism in the influence of the accumulated stress on the affective state of the students, as well as more positive experiences in connection with the social isolation and the perceived perspectives for the future.

The study was conducted using a quantitative and qualitative approach to collecting empirical information.

A battery of three questionnaires and three unfinished sentences was created to collect empirical information, using the capabilities of Google Forms. The created form was sent to students from first to fourth year, Bachelor's degree in the professional field of "Transport, Shipping and Aviation", in the specialties "Maritime Transport Management" and "Logistics" of Nikola Vaptsarov Naval 
Academy. The study is anonymous. The form was fulfilled by 73 of the 92 students to whom the form was sent. Test methods examined the level of optimism and negative expectations, accumulated stress and emotional states.

Used tools for psychological measurement are:

1. Method for assessing optimism and negative expectations. The method was constructed for Bulgarian cultural conditions by A. Velichkov and M. Radoslavova (Velichkov et al. 2005, 27 - 32). The questionnaire consists of 17 statements, divided into two scales - for the study of optimism (10 items) and for negative expectations ( 7 items). The authors of the methodology give the following data for the internal consistency of the scales: for the scale "Optimism" Cronbach's Alpha is 0.79 , and for the scale "Negative expectations" -0.78 .

For the sample that took part in the survey, Cronbach's Alpha for the "Optimism" scale was 0.82 and for the "Negative Expectations" scale -0.74 .

2. Questionnaire for perceived stress - PS-1. The method consists of 14 items. It measures the extent to which subjects evaluate events in their lives as stressful during the last month. In this case, the instruction has been changed, referring to the last months of a pandemic. In this sense, the evaluation relates mainly to perceptions of unpredictability, lack of control and overload, in other words the accumulated stress during the last months. The method is adapted for Bulgarian conditions by A. Rusinova-Hristova and G. Karastoyanov (Karastoyanov et al. 2000). Cronbach's alpha for the present study is 0.89 .

3. Scales for assessing the affective state. The scales were constructed and standardized for Bulgarian cultural conditions by A. Velichkov, based on a method developed by Schimmack \& Grob (2000), which offers a three-dimensional model of the affective state (Velichkov et al. 2005, 57-60). The first dimension is "activation-tension", the second - "activation-cheerfulness", and the third "emotional tone". Each of the dimensions in the proposed instrument is evaluated with two bipolar scales. The three factors are not orthogonal. They are in certain proportions. The summation of the results on the three scales can give an idea of the severity of tension, nervousness, lethargy, fatigue, the experience of sadness and unpleasant feelings, or in the continuum of the other pole is the state of calm, cheerfulness, fresh mood, joy and the experience of pleasant feelings. The scale is processed so that higher values are associated with an unfavorable emotional state. Cronbach's alpha for the present study is 0.88 .

In addition to the listed tools, based on the methodology for conducting qualitative psychological research, the subjects were offered three unfinished sentences, with instructions to read them and immediately fill in the first thoughts that come to mind. The three sentences are as follows:

1. "I am experiencing social isolation during the pandemic ...".

2. "The biggest risk to my future as a result of the pandemic is ...".

3. "I assess my mental state at the moment as ...". 
The content analysis method was used to process the answers to the incomplete sentences. Categories for analysis and units for analysis are structured. Categories for analysis are key concepts in a particular scientific field. In this case, they are from the conceptual field of psychology. Units of analysis are semantic or qualitative units of text content that are related to the categories of analysis. The semantic units can be expressed by a single word, by a word combination, be presented descriptively or by a symbol. In essence, they reflect a certain socially or individually significant topic (Osipov 1983, 295; Todorkov 2002, 192-193). The object of the given research is the individually significant topics stated by the students in their answers at the end of the sentences. The categories for analysis, based on the research model, include: perceived risks for one's own future; social isolation and its impact on students' experiences; the mental state of young people as a result of pandemic experiences.

Statistical analysis of the survey results was performed with SPSS, version 20.

\section{Results}

The results of the scales "Optimism", "Negative expectations", "Accumulated stress" and the scales for affective state were subjected to correlation analysis (Table 1).

Table 1. Correlations between the "Optimism", "Negative expectations" scales and the affective state scales

\begin{tabular}{|l|c|c|}
\hline & Optimism & $\begin{array}{c}\text { Negative } \\
\text { expectations }\end{array}$ \\
\hline Accumulated stress &,$- 531^{* *}$ &, $328^{* *}$ \\
\hline $\begin{array}{l}\text { Tension / } \\
\text { nervousness }\end{array}$ &,$- 499^{* *}$ &, $369^{* *}$ \\
\hline Fatigue / lethargy &,$- 509^{* *}$ &, $333^{* *}$ \\
\hline Sadness / discomfort &,$- 504^{* *}$ &, $325^{* *}$ \\
\hline
\end{tabular}

The results show that optimism correlates moderately but negatively with the accumulated stress, while negative expectations correlate weakly positively with the accumulated stress. Optimism as a personal characteristic is moderately associated with the three dimensions of the affective state, while negative expectations have less pronounced positive relationships. The results of the correlations between optimism and the scales for affective state give rise to expectations for a buffer effect of optimism on the influence of the accumulated stress on the affective state.

In turn, the accumulated stress demonstrates from a significant to a strong positive relationship to tension/nervousness and sadness/discomfort, as dimensions of the affective state and moderate with fatigue/lethargy (Table 2). These results show 
that the accumulation of stress in a pandemic is most significantly associated with changes in the affective state, relating to manifestations of tension and nervousness and the experience of unpleasant emotions.

The comparison of the levels of cumulative stress and the scales related to the affective state of the students from the sample showed that the difference was only statistically significant in the cumulative stress in both sexes (Table 3).

Table 2. Correlations between the "Accumulated stress" scale and the affective state scales

\begin{tabular}{|l|c|}
\hline & $\begin{array}{c}\text { Accumulated } \\
\text { stress }\end{array}$ \\
\hline $\begin{array}{l}\text { Tension / } \\
\text { nervousness }\end{array}$ &, $722^{* *}$ \\
\hline Fatigue / lethargy &, $495^{* *}$ \\
\hline Sadness / discomfort &, $641^{* *}$ \\
\hline
\end{tabular}

**Correlation is significant at the 0.01 level (2-tailed).

Table 3. Results of t-test for differences in mean values on the

"Accumulated stress" scale and the affective state scales in both sexes

\begin{tabular}{|c|c|c|c|c|c|c|}
\hline & Sex* & $\mathbf{N}$ & Mean & $\begin{array}{c}\text { Std. } \\
\text { Deviation }\end{array}$ & $\mathbf{T}$ & Sig. \\
\hline \multirow{2}{*}{$\begin{array}{l}\text { Accumula- } \\
\text { ted stress }\end{array}$} & 1,00 & 12 & 36,67 & 11,90 & \multirow{2}{*}{$-2,006$} & \multirow{2}{*}{,049 } \\
\hline & 2,00 & 62 & 42,39 & 8,43 & & \\
\hline \multirow{2}{*}{$\begin{array}{l}\text { Tension / } \\
\text { Nervousness }\end{array}$} & 1,00 & 12 & 10,08 & 4,60 & \multirow{2}{*}{$-1,510$} & \multirow{2}{*}{, 135} \\
\hline & 2,00 & 61 & 11,90 & 3,65 & & \\
\hline \multirow{2}{*}{$\begin{array}{l}\text { Fatigue / } \\
\text { lethargy }\end{array}$} & 1,00 & 12 & 8,25 & 4,39 & \multirow{2}{*}{$-1,754$} & \multirow{2}{*}{,084 } \\
\hline & 2,00 & 61 & 10,08 & 3,07 & & \\
\hline \multirow{2}{*}{$\begin{array}{l}\text { Sadness / } \\
\text { discomfort }\end{array}$} & 1,00 & 12 & 8,17 & 4,90 & \multirow{2}{*}{,- 780} & \multirow{2}{*}{,438 } \\
\hline & 2,00 & 62 & 9,00 & 3,04 & & \\
\hline
\end{tabular}

*1 - men; 2 - women.

The women in the study group accumulated higher levels of stress, but this did not lead to significant differences in levels of tension, fatigue and sadness in both sexes.

The stepwise regression for the influence of accumulated stress, optimism and negative expectations on the affective state shows (Table 4 and Table 5) that the accumulated stress plays the role of a generator of tension, nervousness, experiencing sadness and unpleasant feelings and fatigue. On the other hand, the optimism has a buffering effect by softening the "blow" of the accumulated stress. 
Negative expectations do not have a statistically significant effect on the affective state.

Table 4. Stepwise regression results for the impact of accumulated stress, optimism and negative expectations on the affective state

\begin{tabular}{|c|c|c|c|c|}
\hline Model & $\mathbf{R}$ & R Square & $\begin{array}{c}\text { Adjusted R } \\
\text { Square }\end{array}$ & $\begin{array}{c}\text { Std. Error of } \\
\text { the Estimate }\end{array}$ \\
\hline $\mathbf{1}$ &, $720^{\mathrm{a}}$ &, 519 &, 511 & 6,49139 \\
\hline $\mathbf{2}$ &, $758^{\mathrm{b}}$ &, 574 &, 561 & 6,15481 \\
\hline $\mathbf{3}$ &, $762^{\mathrm{c}}$ &, 581 &, 561 & 6,15466 \\
\hline \multicolumn{4}{|r}{} \\
\hline
\end{tabular}

a. Predictors: (Constant), Accumulated stress

b. Predictors: (Constant), Accumulated stress, Optimism

c. Predictors: (Constant), Accumulated stress, Optimism, Negative expectations.

Table 5. Coefficients ${ }^{\text {a }}$ from the regression model

\begin{tabular}{|c|c|c|c|c|c|c|}
\hline \multirow{2}{*}{\multicolumn{2}{|c|}{ Model }} & \multicolumn{2}{|c|}{$\begin{array}{l}\text { Unstandardized } \\
\text { Coefficients }\end{array}$} & \multirow{3}{*}{$\begin{array}{c}\begin{array}{c}\text { Standardized } \\
\text { Coefficients }\end{array} \\
\text { Beta } \\
\end{array}$} & \multirow{3}{*}{$\begin{array}{c}\mathbf{t} \\
-, 165 \\
\end{array}$} & \multirow{3}{*}{$\begin{array}{l}\text { Sig. } \\
, 869 \\
\end{array}$} \\
\hline & & $B$ & Std. Error & & & \\
\hline \multirow[b]{2}{*}{1} & (Constant) &,- 624 & 3,774 & & & \\
\hline & $\begin{array}{l}\text { Accumulated } \\
\text { stress }\end{array}$ & ,745 & ,089 & ,720 & 8,369 &, 000 \\
\hline \multirow{3}{*}{2} & (Constant) & 20,685 & 8,215 & & 2,518 & ,014 \\
\hline & $\begin{array}{l}\text { Accumulated } \\
\text { stress }\end{array}$ & ,596 & ,099 & ,576 & 6,012 &, 000 \\
\hline & Optimism &,- 410 & ,142 &,- 276 & $-2,882$ &, 005 \\
\hline \multirow{4}{*}{3} & (Constant) & 15,743 & 9,583 & & 1,643 & ,105 \\
\hline & $\begin{array}{l}\text { Accumulated } \\
\text { stress }\end{array}$ & ,580 & , 100 &, 560 & 5,775 &, 000 \\
\hline & Optimism &,- 361 & ,151 &,- 243 & $-2,393$ & ,020 \\
\hline & $\begin{array}{l}\text { Negative } \\
\text { expectations }\end{array}$ & , 180 & , 180 & ,093 & 1,002 & ,320 \\
\hline
\end{tabular}

a. Dependent Variable: Affective state

Results of the answers to the incomplete sentences:

The unfinished sentence "I experience social isolation during the pandemic .." is related to the category of analysis "social isolation" and its impact on students' experiences.

Two important topics for students are structured. The first topic is intolerance of social exclusion. It is contained in the answers of 37 students $(50.7 \%$ of the 
respondents). For them the tolerance of social isolation is expressed through semantic units, such as: difficult, unpleasant, tense, anxious, demotivating, traumatic, depressing. For $25(34.2 \%)$ of the cited students in the sample, the experience of social isolation is definitely at the pole - severe, traumatic, depressing.

Of the sample, 23 students (31.5\%) experienced social isolation calmly, well, and another $5(6.8 \%)$ with an understanding of the situation. For 3 of the students $(4.1 \%)$ social isolation was experienced as "boring" and several students did not fulfill the sentence.

The results of the t-test for differences in the mean values on the scales "Optimism" and "Negative expectations" in the groups of students who experience social isolation as something severe, traumatic, depressing and those who experience it calmly and with understanding are presented in table 6.

Table 6. Results of t-test for differences in mean values on the "Negative expectations" and "Optimism" scales in the groups of students who find social isolation difficult and those who experience it calmly

\begin{tabular}{|l|c|c|c|c|c|c|}
\hline & $\begin{array}{c}\text { Social } \\
\text { isola-tion }\end{array}$ & $\mathbf{N}$ & Mean & $\begin{array}{c}\text { Std. Devi- } \\
\text { ation }\end{array}$ & $\mathbf{t}$ & Sig. \\
\hline $\begin{array}{l}\text { Negative } \\
\text { expecta- } \\
\text { tions }\end{array}$ & Hardily & 25 & 22,44 & 3,73 & \multirow{2}{*}{3,26} & \multirow{2}{*}{, 002} \\
\cline { 2 - 6 } & Calmly & 28 & 18,71 & 4,58 & & \\
\multirow{2}{*}{ Optimism } & Hardily & 27 & 35,70 & 6,31 & \multirow{2}{*}{, 164} \\
\cline { 2 - 5 } & Calmly & 27 & 38,07 & 6,02 & & \\
\hline
\end{tabular}

Optimism in the two groups is not statistically different, but a significant difference appears in negative expectations. Those who find social isolation difficult have higher levels of negative expectations.

The unfinished sentence "The biggest risk to my future as a result of the pandemic is ..." is linked to the category of analysis - "risk to the future" of young people as a result of the pandemic. There are two important topics identified in the answers for students.

The first topic concerns the expected career risks and difficulties in finding a job. This risk is associated with the economic cataclysms caused by the pandemic. The topic is important for 21 students $(28.8 \%$ of the respondents).

For 17 students $(23.3 \%)$ the main risk in perspective, as a consequence of the pandemic, comes from the acquired knowledge and skills formed during online learning, or rather from doubts about the quality of online learning.

For $4(5.5 \%)$ students the most significant risk is for the economy and financial stability of the country. 
For 9 students $(12.3 \%)$ there are no risks for their future, as a result of the pandemic, another $3(4.1 \%)$ do not know what risks there would be.

There are also specific topics for individual students, such as: risk of losing the sense of smell forever, for mental health, for vision from constant use of a computer.

This sentence was not completed by 16 persons $(21.9 \%)$ from the sample.

No statistically significant differences were found, by multivariate analysis of variance, on the "Optimism" $(\mathrm{F}=0.861, \mathrm{p}=0.512)$ and "Negative Expectations" $(\mathrm{F}=0.688, \mathrm{p}=0.635)$ scales between groups of students who developed different significant topics related to the unfinished sentence "The biggest risk to my future as a result of the pandemic is ...".

Obviously, the differences in the significant topics for probable risks arise from other factors that are not the subject of the present study, but optimism and negative expectations do not affect them.

The unfinished sentence "I assess my mental state at the moment as ..." is related to the category of analysis - "mental state" of young people in a pandemic. Three important topics for the students are derived from the answers to the sentence.

The first topic is the "and so and so", "unstable", "shaken", "depressed" mental state. In this way, 29 of the respondents $(39.7 \%$ of the respondents) described their mental state, and for $25(34.2 \%)$ of them it was definitely shaken, depressed.

For 35 students $(47.9 \%)$ their mental state is good, stable, normal. The sentence was not completed by 9 students $(12.3 \%)$.

A $\mathrm{t}$ - test was made (Table 7) for differences in the mean values on the scales "Optimism" and "Negative expectations" in the groups of students who give a selfassessment of their mental state as good, stable and those who describe it as shaky, depressed. Statistically significant differences were observed on both scales.

Table 7. Results of t-test for differences in mean values on the "Optimism" and "Negative expectations" scales in the groups of students who assess their mental state as good, stable and those who assess it as shaky

\begin{tabular}{|l|c|c|c|c|c|c|}
\hline & $\begin{array}{c}\text { Self- } \\
\text { assess- } \\
\text { ment of } \\
\text { mental } \\
\text { state }\end{array}$ & $\mathbf{N}$ & Mean & $\begin{array}{c}\text { Std. } \\
\text { Devia- } \\
\text { tion }\end{array}$ & $\mathbf{t}$ & Sig. \\
\hline \multirow{2}{*}{ Optimism } & $\begin{array}{c}\text { Good, } \\
\text { stable }\end{array}$ & 36 & 38,83 & 5,15 & \multirow{2}{*}{3,652} &, 001 \\
\cline { 2 - 8 } & Shaken & 25 & 33,08 & 6,61 & & \\
\hline $\begin{array}{l}\text { Negative } \\
\text { expecta- } \\
\text { tions }\end{array}$ & $\begin{array}{c}\text { Good, } \\
\text { stable }\end{array}$ & 36 & 19,36 & 4,77 & \multirow{2}{*}{$-3,032$} &, 004 \\
\cline { 2 - 8 } & Shaken & 24 & 22,88 & 4,13 & & \\
\hline
\end{tabular}


Those who define their mental state as good, stable have higher values of optimism, as well as lower values of negative expectations.

\section{Discussion}

The results of the study show the significant influence of the generalized expectation "Optimism" on the accumulation of stress and the affective state of students in the conditions of a pandemic of COVID-19. Students with more optimism have lower levels of tension, nervousness and experiencing unpleasant emotions, perceive their mental state as better and more stable, than those with lower levels of optimism.

Optimism buffers the negative impact of accumulated stress in the conditions of a pandemic and softens its impact on the experiences of tension and nervousness. This confirms the initial hypothesis.

Negative expectations do not significantly affect the affective state in the regression model, but significantly affect self-esteem for the mental state, which is important for the overall mental well-being, and with the intensification of these expectations, lower self-esteem leads to a more shaky and unstable mental state.

No significant effects of the optimism and negative expectations of students on perceived risks for their future and career were found as a result of the pandemic. This is somewhat unexpected, but it shows that the conditioning of students' experiences is more complex and probably here the processes of rational processing of the situation and the assessment of deficits in distance learning have a tangible impact.

The presence of doubts by students about the quality of education should provoke a new attitude from higher education institutions to this problem. It should be in the direction of taking in discussion with students and with their consent to compensatory measures - additional testing, detection of deficits in training, training on issues that are less mastered, and more. In addition, it is important to advise students who need support due to the psychological consequences of the pandemic and due to specific individual experiences caused by obstacles of the disease for the students themselves and for their relatives.

The results also show that in such situations, psychological counseling and closer contact with students are important to overcome the negative effects of social isolation and social constraints. It is the growing impression that, following the example of functioning psychologists in secondary education, psychological services are also needed in higher education. The pandemic shows the urgent need for them.

\section{Conclusions}

The study showed its expediency and the need for new policies of higher education institutions in such crisis situations. The training of future specialists in 
higher education is not and cannot be concentrated only on acquiring knowledge and formation of skills and narrow professional competencies. The training of specialists in higher education is, above all, the complete maturing of the personality, the formation of motivation for leadership and career development, the formation of resilience and optimism. These are the future leaders in society and it is important that they are prepared and have a model for dealing with such crises in the future.

\section{REFERENCES}

Djonev, S., 2015. Kachestveni metodi za izsledvane v socialnite nauki. Sofia: En Dji Bi Konsulting [in Bulgarian].

Domuschieva-Rogleva, G. \& Savcheva, E., 2020. The Psychological Impact of COVID-19 on University Lecturers in the Field of Sports Education. Pedagogika-Pedagogy 92(7s), 163 - 175.

Iancheva, T., 2020. Psychological Consequences of Self-Isolation and Online Education of Sports Students during a Pandemic. PedagogikaPedagogy 92(7s), $152-162$.

Karastoyanov, G. \& Rusinova-Hristova, A., 2000. Bulgarska adaptatsiya na vaprosnika za vazpriet stress. Psihologichni izsledvaniya $(1-2)$ [in Bulgarian].

Lazarus, R., 1999. Stress and Emotion. A new Syntesis. N.Y.: Springer Publishing Company Inc.

Naydenova, K. \& Chernev, K., 2020. Distance Learning in the Conditions of COVID-19, the Point of View of Students and Pupils. PedagogikaPedagogy 92(7s), 260 - 267.

Osipov, G. (ed.), 1983. Rabochaia kniga sociologa. Moscow: Nauka, 2-e izdanie [in Russian].

Todorkov, K., 2002. Eksperimentalna psihologia. Veliko Turnovo: Faber [in Bulgarian].

Velichkov, A., 2001. Predpolagaemite svetove na lichnostta. Sofia: Institut po Psyhologia na MVR [in Bulgarian].

Velichkov, A. \& Radoslavova, M., 2005. Metodi za psichodiagnostica. Sofia: Pandora Prim [in Bulgarian].

$\triangle$ Valeri Stoyanov

ORCID iD: 0000-0003-0531-6103

Nikola Vaptsarov Naval Academy

Varna, Bulgaria

E-mail: v.stoyanov@nvna.eu 